\title{
STUDY ON EVALUATION AND MANAGEMENT OF HAND INJURIES
}

\author{
Manimaran Thangavelu1, Nagarajan Veerasamy2 ${ }^{2}$ Anandan Kanthan ${ }^{3}$ \\ ${ }^{1}$ Assistant Professor, Department of General Surgery, KAPV Govt. Medical College, Trichy. \\ 2Postgraduate Student, Department of General Surgery, KAPV Govt. Medical College, Trichy. \\ ${ }^{3}$ Postgraduate Student, Department of General Surgery, KAPV Govt. Medical College, Trichy.
}

\section{ABSTRACT}

\section{BACKGROUND}

Hand injuries are common accounting for nearly $10 \%$ of hospital emergency department visits. Aim of this study is to evaluate the peculiarities of the epidemiology of the various causes of hand injury in our locality, various pattern of presentation, various treatment modalities adopted in our institution.

\section{MATERIALS AND METHODS}

This study was conducted at Mahatma Gandhi Memorial Hospital, KAPV Govt. Medical College, Trichy. 200 cases of hand injuries admitted from July 2015 to February 2016 evaluated.

\section{RESULTS}

In our study, young adult individuals affected more than older age group. Incidence highest in the age group of 21 - 30 years (28.5\%). Male - 161 cases (80.5\%). Female - 39 cases (19.5\%). Most common cause is industrial injuries followed by road traffic accident, cracker burst injury. Right hand commonly injured than left hand. Most wounds are tidy wounds (86.5\%). Complex injury common than isolated part of hand injury. Most of the complex injuries are due to industrial injury. Among tendon injuries, extensor tendons commonly injured than flexor tendons. Flexor zones commonly injured than extensor zone. Among these, commonly injured is zone II flexor injury. In our institution, $77 \%$ of cases intervened within $8 \mathrm{hrs}$. of injury, remaining $23 \%$ within $48 \mathrm{hrs}$. All the cases of hand injury treated according to pattern of injury and nature of wounds. Some cases of amputation with clean and cut injury, repositioning of amputated part done. Bone injuries reduced and stabilised using Kirschner wire, tendon injuries primary suturing done if less than 24 hours, neurovascular injury primary suturing done with 6-0 Prolene.

\section{CONCLUSION}

Hand injuries needs very good surveillance not to miss any of the potential injures. The goal of the surgeon is to know which injuries need immediate intervention. Early intervention, appropriate management, follow up, and rehabilitation gives better results.

\section{KEYWORDS}

Hand Injury, Nature, Type, Zone, Time of Repair.

HOW TO CITE THIS ARTICLE: Thangavelu M, Veerasamy N, Kanthan A. Study on evaluation and management of hand injuries. J. Evolution Med. Dent. Sci. 2016;5(66):4703-4706, DOI: 10.14260/jemds/2016/1072

\section{INTRODUCTION}

Hand injuries constitute a major proportion of injuries seen in many hospitals worldwide. 1 The occurrence is on the rise, especially because there is a general increase in violence and injuries in emerging economies. ${ }^{2}$

Injuries to the hand are often neglected especially when they occur in combination with injuries to other parts of the body. Hand injuries occur mainly among young adults. ${ }^{1,3}$ Many of these injuries affect the dominant hand ${ }^{4,5}$ thereby impeding patients' ability to work or cope with their social obligations. ${ }^{1,6}$ Hand injuries mainly occur on the road, in the work place, and at home.1,3,5,7 Often great social and economic losses are encountered because of these injuries. ${ }^{6}$ Severe hand injuries are usually due to gunshot or machine injuries and often require admission and surgical intervention.1,5 A large proportion are minor injuries. ${ }^{3}$

Financial or Other, Competing Interest: None.

Submission 08-07-2016, Peer Review 01-08-2016,

Acceptance 09-08-2016, Published 17-08-2016.

Corresponding Author:

Dr. Manimaran Thangavelu,

Assistant Professor

Department of General Surgery,

KAPV Govt. Medical College,

Trichy.

E-mail: drnagarajanv75@gmail.com

DOI: $10.14260 /$ jemds/2016/1072
The severity of a hand injury can be readily assessed by use of the Hand Injury Severity Score (HISS) developed by Campbell and Kay. ${ }^{8}$

Because surgical intervention looks to evidence-based practice to improve patient care, it is important to determine the causes of hand injuries in this environment. This study was geared toward reducing the incidence and severity of hand injuries in our society.

\section{MATERIALS AND METHODS}

Study Place: Mahatma Gandhi Memorial Hospital and KAPV Govt. Medical College. Trichy.

Duration of Study: July 2015 to February 2016.

Study Design: Prospective Study.

Ethical Committee: Institutional Ethical Committee, KAPV Govt. Medical College. Approved on June 2015.

\section{Inclusion Criteria}

All age group with hand injury, all sex group, Male, Female, and transgenders. Patients with open compound hand injuries and closed tendon injuries.

\section{Exclusion Criteria}

Associated other injuries and cases admitted after 24 hours of injury were excluded. 


\section{Data Collection and Methods}

Patients admitted with hand injury at Mahatma Gandhi Memorial Hospital, Trichy were included in the study. History evaluation with structured questionnaire along with clinical examination of the patient. X-ray of hand was taken to know about bone injuries. In suspected cases of vascular injuries, Doppler study of hand done. All the patients treated according to their injury with various treatment modalities. I have selected 200 cases of hand injury admitted and managed in our hospital during this period. Surgical management is done depending on the type of injury and with plastic surgeons assistance.

The demographic data recording age, sex, handedness, place, and cause of hand injuries retrieved and analysed. The pattern of hand injuries, types of wound, part of hand injured, and time of intervention are analysed.

\section{RESULTS}

\section{Age Distribution}

In our study, young adult individuals affected more than older age group. Incidence highest in the age group of 21 - 30 years (28.5\%) followed by $31-40$ years (20\%), and $11-20$ years (19\%).

\begin{tabular}{|c|c|c|}
\hline Age Group & No. of Patients & Percentage \\
\hline 0 - 10 years & 12 & $6 \%$ \\
\hline $11-20$ years & 38 & $19 \%$ \\
\hline $21-30$ years & 57 & $28.5 \%$ \\
\hline $31-40$ years & 40 & $20 \%$ \\
\hline $41-50$ years & 35 & $17.5 \%$ \\
\hline $51-60$ years & 12 & $6 \%$ \\
\hline$>60$ years & 6 & $3 \%$ \\
\hline \multicolumn{3}{|c|}{ Table 1 } \\
\hline
\end{tabular}

\section{Sex Distribution}

In our study, among 200 patients, male - 161 cases (80.5\%), female - 39 cases (19.5\%). Male individuals commonly injured than females.

\section{Causes of Hand Injuries}

In our study, most common cause of acute traumatic hand injury is industrial (worksite) related injuries. Next common cause is Road Traffic Accident followed by Assault, Cracker burst, and Accidental injury.

\begin{tabular}{|c|c|c|}
\hline Cause & No. of Patients & Percentage \\
\hline Road traffic accident & 47 & $23.5 \%$ \\
\hline Industrial (Worksite) & 67 & $33.5 \%$ \\
\hline Assault & 44 & $22 \%$ \\
\hline Cracker burst & 23 & $11.5 \%$ \\
\hline Accidental injury & 19 & $9.5 \%$ \\
\hline \multicolumn{3}{|c|}{ Table 2 } \\
\hline
\end{tabular}

Right hand commonly injured 107 cases (53.5\%), left hand 88 cases (44\%), and both hands 5 cases (2.5\%).

\section{Types of Wound}

Most of wounds in our study are tidy wounds (86.5\%), remaining wounds $(13.5 \%)$ untidy wounds. Untidy wounds commonly due to cracker burst injury.

\section{Pattern of Injuries}

In this study, complex injury common than individual part of hand injury. Most of the complex injuries are due to industrial injury. Next common is soft tissues and amputation injury. Among tendon injuries, extensor tendons commonly injured than flexor tendons. Neurovascular injury occurred in less no. of cases.

\begin{tabular}{|c|c|c|}
\hline Parts of Hand Injury & No. of Patients & Percentage \\
\hline Soft tissues & 34 & $17 \%$ \\
\hline Bone & 31 & $15.5 \%$ \\
\hline Amputation & 32 & $16 \%$ \\
\hline Flexor tendon & 23 & $11.5 \%$ \\
\hline Extensor tendon & 29 & $14.5 \%$ \\
\hline Neurovascular & 10 & $5 \%$ \\
\hline Complex injury & 41 & $20.5 \%$ \\
\hline \multicolumn{3}{|c|}{ Table 3 }
\end{tabular}

\section{Zones of Injury}

Flexor aspect commonly injured 131 cases (65.5\%) than extensor aspect 69 cases (34.5\%).

\section{Flexor Zone Injury}

\begin{tabular}{|c|c|c|}
\hline Zone & No. of Patients & Percentage \\
\hline I & 29 & $14.5 \%$ \\
\hline II & 59 & $29.5 \%$ \\
\hline III & 19 & $9.5 \%$ \\
\hline IV & 10 & $5 \%$ \\
\hline V & 23 & $11.5 \%$ \\
\hline \multicolumn{3}{|c|}{ Table 4 } \\
\hline
\end{tabular}

\section{Extensor Zone Injury}

\begin{tabular}{|c|c|c|}
\hline Zone & No. of Patients & Percentage \\
\hline I & 19 & $9.5 \%$ \\
\hline II & 8 & $4 \%$ \\
\hline III & 7 & $3.5 \%$ \\
\hline IV & 3 & $1.5 \%$ \\
\hline V & 5 & $2.5 \%$ \\
\hline VI & 6 & $3 \%$ \\
\hline VII & 12 & $6 \%$ \\
\hline VIII & 9 & $4.5 \%$ \\
\hline \multicolumn{3}{|c|}{ Table 5 } \\
\hline
\end{tabular}

\section{Time of Intervention}

In our institution, $77 \%$ of cases intervened within $8 \mathrm{hrs}$. of injury and $23 \%$ within $48 \mathrm{hrs}$.

\section{Treatment}

All the cases of hand injury treated according to pattern of injury and nature of wounds and others.

Soft Tissue Injury: Soft tissue injury treated with different modality. Primary closure, V-Y volar flap, Crossed finger flap, Split skin Graft, Nail injury - Repositioning.

Amputation Injury: Most of the cases of amputation injury are crushed injury. These cases treated with wound debridement, shortening, and closure at appropriate level. Some cases of amputation injury clean and cut injury. In these cases, repositioning of amputated part done.

Bone Injury: Phalanx fracture is common presentation of bone injury followed by joint dislocation in our study. In all cases, reduction and stabilisation of bone done with K-wire fixation and splinting. 
Tendon Injury: Both flexor and extensor tendon injuries repaired by primary tendon repair (within 12-24 hrs. of injury) with modified Kessler technique by using 4-0 nylon for smaller size tendons 5-0 used.

Neurovascular Injury: Isolated neurovascular injury is rare in our study mostly associated with other injuries. Nerve and vessel injury repaired by primary repair with fine sutures like 6-0 Prolene. Proper postoperative splinting and rehabilitation done with regular followup.

\section{DISCUSSION}

The hand is a very intricate and important tool used for daily living activities. In the developing world, it establishes the individual in society, allowing them to meet social and economic responsibilities. It is therefore important to understand the causes of injury to this part of the body to minimise the occurrence of injury and to forestall poor treatment outcomes that may result in dramatic reduction in quality of life. In this study, young adults were most commonly affected. This finding is consistent with other series in which the average age was less than 30 years. ${ }^{1,3,6,7}$ However, studies in areas with considerable post productive populations show a slightly higher average age group of 40 years. Most studies show a male predominance with a male-to-female ratio of $4: 1.1,7,9$ In our series, we had a higher incidence of injury among men, but with a similar margin of $4: 1$.

The report of hand injuries by Beaton and colleagues 4 showed results similar to ours where right hand injuries were more common than left hand injuries. Similar to other studies, $53.5 \%$ of our patients sustained an injury to their dominant hand. These studies reported more than $50 \%$ of injuries to the dominant hand. ${ }^{1,3}$ However, Mink and colleagues ${ }^{10}$ observed dominant hand injuries in about $37 \%$ of their sample. In this study, $12 \%$ had a hand injury in combination with other injuries, which was in contrast with another study in which $4 \%$ had combined injuries. ${ }^{11}$ In our study, about $2.5 \%$ sustained injury to both hands. A $2 \%$ rate of injury to both hands has previously been reported. ${ }^{1}$

Trybus and colleagues ${ }^{1}$ performed a study in an industrial city in Poland in which about $50 \%$ of workers with a hand injury were manual workers. However, in our study, semiskilled workers such as technicians and public servants constituted more than half of all patients with hand injuries. This underscores the important fact that more than $50 \%$ of people who sustain hand injuries in our environment are in the work force. It is pertinent to observe that in many studies undertaken in industrialised nations, machine injury is the most common cause of hand injury.1,7 In our environment, motor vehicle collision was the next cause of hand injury followed by machine injury. This maybe because of the fact that this study was carried out in an environment with fewer industries and a high rate of vehicular collisions. We also observed that more than half of the engineers and technicians had injuries sustained from machine accidents. The civil and public servants had most of their injuries from motor vehicle collisions; this is probably explained by the fact that these professionals are regular commuters.

No cases of our patients sustained their injuries from gunshot incidents. This was nearly the finding of other investigators who rarely reported gunshot injuries to the hand. 1,5,7

Injuries due to ring entrapment were not often reported in other studies; however, one case in this series sustained this form of injury and was female had vascular complication as a result of prompt vascular repair viability maintained. Men are more likely to sustain hand injury from violent causes such as traffic accidents, gunshot, and machine injuries. Ahmed and Chaka $^{7}$ noted similar findings in a study in Ethiopia. Sports injuries to the hand were not seen in our study; however, a rate of sports-related hand injuries of $31 \%$ was reported in a European study. ${ }^{3}$

In our series, most injuries occurred on the road (23.5\%) and in the workplace $(33.5 \%)$. Other studies also reported more workplace injuries. $5,7,10$ Trybus and colleagues ${ }^{1}$ reported that $45 \%$ of injuries in their study occurred in the home, followed by $20 \%$ in the workplace. These results are similar to those from a study conducted in Finland. ${ }^{11}$ Some earlier reports showed that home injuries are commonly due to glass or knife cuts.1,6,12 This is not consistent with our findings. This is probably because most home injuries are minor and treated in nearby clinics.

The meantime between occurrence of injury and admission was 18.3 hours; this is close to the findings of other surveys. ${ }^{1}$ However, it is important to note that patients with machine injuries were brought to the hospital relatively earlier with an average time between injury and admission of 5.4 hours. This is in contrast to the results of a study conducted in Ethiopia7 in which the average time between mechanical injury and presentation was 8 hours.

Consideration was given to the injury distribution within the zones of the hand. We observed that zone 2 had the highest risk of being injured (33.5\%). Fingertip injuries accounted for almost $7.4 \%$ of cases, but were mainly seen in children.13 However, $21 \%$ of cases involved injury to more than one zone. As in other series, the skeleton and integument were the tissue components most commonly injured.5,7 High-energy injuries from machinery have a higher risk of involving of all the tissue components and increasing the potential of digit amputation. $5,7,8,14$

In a recent evaluation of 140 cases, $52 \%$ of injuries were minor, $29 \%$ were moderate, $12 \%$ were severe, and $6 \%$ were major. ${ }^{15}$ In our series, $27 \%$ were classified as minor, $38 \%$ were moderate, $19 \%$ were severe, and $16 \%$ were major injuries. Thus, more than $60 \%$ of our cases fell within the minor and moderate classification. Other series have also reported that more than $60 \%$ of cases are minor or moderate. 11,15 Furthermore, this study also demonstrated that most (60\%) of admissions had a severe or major HISS injury classification.

\section{CONCLUSION}

In conclusion, we have shown that hand injuries constitute a major proportion of trauma emergencies in a developing country, machine injury is the major cause. It is imperative that education for drivers and other road users coupled with adequate enforcement of traffic regulations to reduce the incidence of hand injury. Although, a large percentage of machine injuries are minor. More than half of the people with this type of injury are from the working class and are the driving force of the country's economy. A substantial number of these workers face the risk of losing their employment and having their social status irreparably altered. This, in turn, 
leads to major economic loss. We also observed that workers who sustained machine injuries usually had severe to major forms of injury, which included amputation of digits. It is therefore recommended that employers and government focus more effort toward worker education, particularly with regards to occupational health and safety. The provision of a safe and work-friendly environment includes training in equipment operation and maintenance and the provision of appropriate protective clothing and safeguarding of machinery. Furthermore, it is essential that policy measures be put in place for insurance and adequate compensation of the hand injury related disability.

Hand injuries needs very good surveillance not to miss any of the potential injures. The goal of the surgeon is to know which injuries need immediate intervention. Early intervention, appropriate management, followup, and rehabilitation gives better results.

\section{REFERENCES}

1. Trybus M, Lorkowski J, Brongel L, et al. Causes and consequences of hand injuries. Am J Surg 2006;192(1): 52-7.

2. Mock C, Quansah R, Kobusingye 0, et al. Trauma care in Africa: the way forward. African J Trauma 2004;2:53-8.

3. Rosberg HE, Dahlin LB. Epidemiology of hand injuries in the middle-sized city in southern Sweden: a retrospective comparison of 1989 and 1997. Scand J Plast Reconstruct Surg Hand Surg 2004;38(6):347-55.

4. Beaton AA, William L, Moseley LG. Handedness and hand injuries. J Hand Surg Br 1994;19(2):158-61.
5. Saxena P, Cutler L, Feldberg L. Assessment of the severity of hand injuries using hand injury severity score and its correlation with functional outcome. Injury 2004; 35(5):511-6.

6. Trybus M, Guzik P. Occupational hand injuries. Med Pr 2004;55(4):341-4

7. Ahmed E, Chaka T. Prospective study of patients with hand injury: Tikur Anbessa University Teaching Hospital, Addis Ababa. Ethiop Med J 2006;44(2):175-81.

8. Campbell DA, Kay SP. The hand injury severity scoring system. J Hand Surg Br 1996;21(3):295-8.

9. O'Sullivan ME, Colville J. The economic impact of hand injuries. J Hand Surg Br 1993;18(3):395-8.

10. Mink van der Molen AB, Ettema AM, Hovius SE. Outcome of hand trauma: the Hand Injury Severity Scoring System (HISS) and subsequent impairment and disability. J Hand Surg Br 2003;28(4):295-9.

11. Nieminen S, Nurmi M, Isberg U. Hand injuries in Finland. Scand J Plast Reconstr Surg 1981;15(1):57-60.

12. Ousby J, Wilson DH. 1086 consecutive injuries caused by glass. Injury 1982;13(5):427-30.

13. Ljungberg E, Rosberg HE, Dahlin LB. Hand injuries in young children. J Hand Surg Br 2003;28(4):376-80.

14. Olaitan PB, Jiburum BC. A review of amputation of 106 hand digits. Nigerian J Orthop Trauma 2008;7(1):3-6.

15. Rosberg HE, Carlsson KS, Dahlin LB. Prospective study of patients with injuries to the hand and forearm: costs, function, and general health. Scand J Plast Reconstr Surg Hand Surg 2005;39(6):360-9. 